\title{
Damage of the Cell Wall During Extrusion and Injection Molding of Wood Plastic Composites
}

\author{
William Gacitua E. ${ }^{1 *}-$ David F. Bahr ${ }^{2}$ - Michael P. Wolcott ${ }^{3}$ \\ ${ }^{1}$ Assistant professor, Departamento Ingenieria en Maderas - Universidad del \\ Bio-Bio. Collao 1202 Concepción-CHILE. \\ * Corresponding author \\ wgacitua@ubiobio.cl \\ ${ }^{2}$ Associate Professor, College of Engineering \& Architecture, School of \\ Mechanical and Materials Engineering, Washington State University, \\ Pullman WA, USA. \\ ${ }^{3}$ Professor and Research Director, Wood Materials \& Engineering \\ Laboratory, Washington State University, Pullman WA, USA. \\ wolcott@wsu.edu
}

\begin{abstract}
To study material damage in wood cells during any transformation process, one must consider the molecular architecture of natural cellulosic fibers, which may eventually impact the overall mechanical behavior of wood fibers. In particular wood species, anatomical features and mechanical properties of the cell wall may determine the potential for stress transfer in hybrid materials. The wood cell damage was quantified in terms of the stiffness reduction of the S2 layer by measuring Young's modulus with nanoindentations before and after processing. A modified rule of mixture based on a damage parameter affected by the latewood proportion and cell wall properties was proposed and validated.
\end{abstract}

Keywords: A. Wood, C. Damage mechanics, B. Mechanical properties, A. High density polyethylene. 


\section{Proceedings of the 51st International Convention of Society of Wood Science and Technology November 10-12, 2008 Concepción, CHILE}

\section{Introduction}

Wood cell architecture may suffer significant changes due to loading, heating conditions and physical-chemical environments during WPC (wood plastic composites) production. Extreme processing conditions may induce structural damage of wood flour particles, evidenced as bucking, cellular collapse and eventually fracture in cell walls, and consequently a poor reinforcement of the thermoplastic phase. Inside the primary wall of wood cells is the secondary wall, composed of a thin outer layer (S1), broad central layer (S2), and thin inner layer (S3). The S2 layer represents the major component of the cell wall, and its microfibrils are more longitudinally directed, explaining its relevance in terms of the mechanical properties of the cell wall and of wood [5-6-7]. This cell ultrastructure of the natural filler for WPCs may be altered in processing, resulting in plastic flow and eventually fracture at the microfibril or nanoscale level. In related literature, damage to composites is referred to as failure of the fiber-matrix interface, matrix cracking or crazing, fiber breaking and void growth [1]. Geimer, et al. studied damage in wood composites [2] and found no microscopic internal damage during the flaking process to produce flakeboards; but, the flakes did suffer internal damage during hot pressing resulting in lower mechanical properties, and evidenced in buckling, shearing and bending failure, most frequently in earlywood. More research needs to be done to quantify the actual damage in WPC, particularly in the filler material. In our research, we quantified wood cell damage in terms of the stiffness reduction of the S2 layer for the cell wall by measuring Young's modulus with nanoindentations on the cell wall before and after processing.

\section{Materials and Methods}

In this study, we determined nanomechanical and localized properties (mainly of the S2 layer and middle lamella) before processing solid wood samples. We also established the potential decrease in mechanical properties for wood and proposed a modified rule for mixture.

Materials. Two wood species, Grand fir (GF) and Lodgepole pine (LP) were used to produce wood flour and composites with HDPE (high density polyethylene, Equistar LB 0100-00) as the matrix. Ponderosa pine and polypropylene (PP) were then used to validate the proposed model. The lubricant, Strucktol TPW113, was added to the formulation.

Nanoindentation on solid wood. A Triboscope Hysitron Nanomechanical test instrument was used to quantify the mechanical properties of the cell wall. Indentations were performed in earlywood and latewood cells, and also in the middle lamella of solid wood samples. A Berkovich-type triangular pyramid indenter was used in a loading cycle with $300 \mu \mathrm{N}$ nominal force. In an individual indentation experiment, the peak load $\left(\mathrm{P}_{\max }\right)$, the depth at peak load (h) and the initial unloading stiffness (S), which is the slope of the unloading curve, were obtained. The geometry of the indenter and h, the contact area (A) was also calculated. Then, the reduced modulus $\left(\mathrm{E}_{\mathrm{r}}\right)$ is determined according the equation: 


$$
E_{r}=\frac{\sqrt{\pi}}{2} \frac{S}{\sqrt{A}}
$$

The main idea is that even for materials which exhibit plastic deformation during loading, the initial unloading is elastic. Thus, the initial slope of the unloading curve is directly related to the elastic modulus [8-9]. When $\mathrm{E}_{\mathrm{r}}$ is a resultant of the elastic deformation of the indenter and the sample, then the reduced elastic modulus is:

$$
E_{r}=\left[\frac{1-v_{s}^{2}}{E_{s}}+\frac{1-v_{\mathrm{i}}^{2}}{\mathrm{E}_{\mathrm{i}}}\right]^{-1}
$$

where the sub-indexes $s$ and $i$ represent the sample (cell wall, S2 layer) and indenter respectively and $v$ is Poisson's ratio. The indenter modulus, $\mathrm{E}_{\mathrm{i}}$, is constant and equal to $1240 \mathrm{GPa}$, with a Poisson's ratio equal to 0.07 . A Poisson's ratio of 0.34 and 0.33 is assumed for Grand fir and Lodgepole pine respectively [12]. For HDPE, a Poisson's ratio of 0.3 was assumed. For each wood species, $5 \mathrm{~mm}$ cubes were prepared for indentation. Nanoindentations on the cell wall, S2 layer, and the middle lamella were performed for latewood and earlywood cells.

Extrusion and injection: damage to the cell wall after processing. Wood flour-HDPE composites ( $40 \%$ wood by weight) were made in an $18 \mathrm{~mm}$ twin screw extruder followed by injection molding (Sumitomo SE 50D). Then, to validate a proposed prediction model, composites made of PP and Ponderosa pine wood flour were produced with inclusion of $4 \%$ of lubricant using a series of wood/PP proportion. Then tensile specimens according to ASTM D638 were obtained. A morphology analysis on cross sections of tensile samples was conducted using a Hitachi S-570 scanning electron microscope (SEM). The axial modulus of random undamaged and buckled wood cells on cross sections of WPC samples was determined using nanoindentations.

Modified rule of mixture and processing damage parameter. A semi-empirical model to predict the axial modulus of experimental composites was developed based on the wood cell damage due to the processing and the well known Rule of Mixture (ROM). The damage parameter was experimentally determined based on nanoindentation measurements in the cell wall, which allowed the calculation of Young's modulus of the cellular filler before and after processing. The damage parameter for wood cells takes into account reduction in modulus, moisture content and latewood-earlywood proportion of the species used. The relative reduced Young's modulus of the cell walls due to the processing conditions, $E_{D}$, was estimated as:

$$
E_{D}=\frac{E_{b}-E_{a}}{E_{b}}
$$

where, $E_{b}$ and $E_{a}$ are the axial modulus or Young's modulus of the cell wall measured before and after processing. Nanoindentations were used to quantify $E_{b}$ and $E_{a}$, and $E_{D}$ 
was determined either for earlywood $\left(E_{D E}\right)$ of latewood $\left(E_{D L}\right)$. The resulting damage parameter $D$ is:

$$
D=D_{E}+D_{L}=E_{w}\left(1-E_{D E}\right)+L_{w}\left(1-E_{D L}\right)
$$

where $D_{\mathrm{E}}$ and $D_{L}$ are damage parameters for earlywood and latewood respectively. Finally, the Modified Rule of Mixture (MROM) to take filler mechanical damage into account is:

$$
E_{1}=D E_{1}^{f} V^{f}+E^{m}\left(1-V^{f}\right)
$$

\section{Results}

Micro-properties of wood components and wood specie effect. The elastic modulus of the cell wall is consistent with values reported by other authors in species such as Norway spruce and Red spruce [3-4-11]. The elastic modulus of the cell wall for latewood was about $17 \mathrm{GPa}$ and $14 \mathrm{GPa}$ for earlywood in both wood species. The average modulus for the middle lamella in Grand fir was approximately $11.5 \mathrm{GPa}$, slightly higher than the elastic modulus for the middle lamella of Lodgepole pine samples, which was about $9 \mathrm{GPa}$. Measurements performed on the middle lamella showed high variability. More important is the role of mechanical properties of the middle lamella on transverse fiber-wood properties [7]. The differences in the modulus of the middle lamella between Grand fir and Lodgepole pine may partially explain the response of wood particles during extrusion-injection in terms of the final cellular collapse that we saw in experimental WPC after processing (Figure 1b). Cellular collapse was more evident in Lodgepole pine cells, which usually have a lower modulus in the middle lamella.

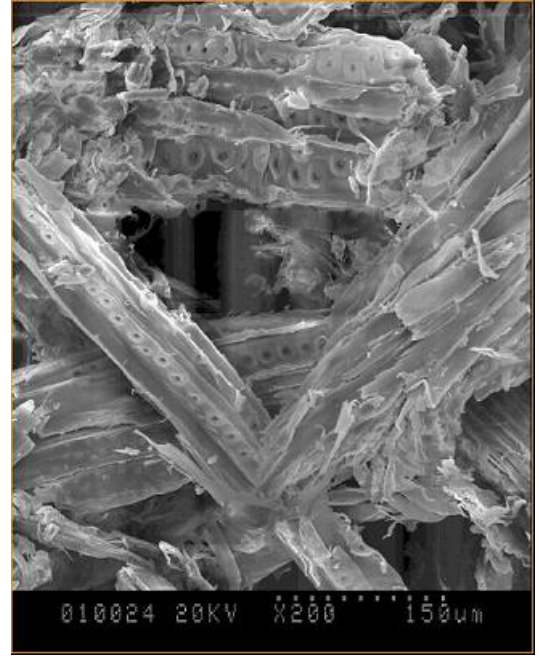

a)

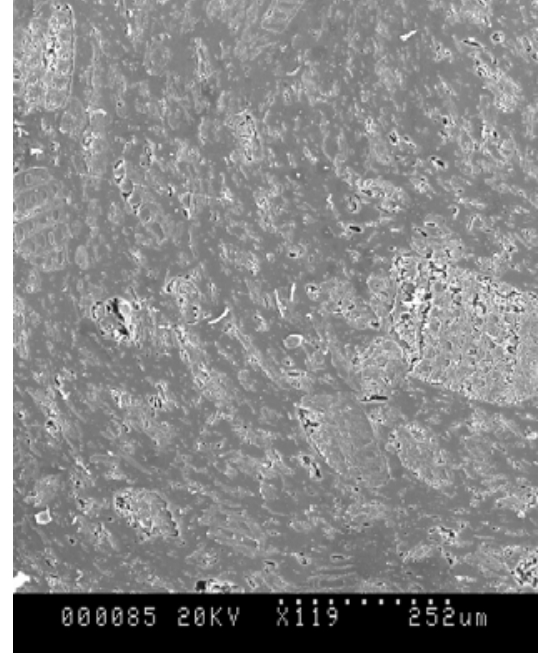

b)

Figure 1: SEM analysis of damage of the cellular filler during processing. a) after milling (wood flour 60 mesh), b) after extrusion-injection, 40\% weight fraction for wood. Wood specie is lodgepole pine, outerwood. 


\section{Proceedings of the 51st International Convention of Society of Wood Science and Technology November 10-12, 2008 Concepción, CHILE}

Properties of phase's composite. This experiment quantified the individual properties of each phase of the composite and produced direct measurements that may be used in prediction models for better estimations of design properties of WPCs. First, it is necessary to point out the significant damage that can affect wood particles during size reduction and thermomechanical processes such as in hammer milling and extrusioninjection molding. Figure 1a shows the abrupt separation or fracture of wood cells after being processed in a hammer mill. This picture shows the non-uniform morphology of wood flour particles and also an irregular surface which will interact with the molten thermoplastic in the extrusion. Figure 1b shows a characteristic cross section of an experimental composite evidencing cellular collapse and, in some cases, cell wall fracture. Results suggest that cumulative damage of the cellular material can affect the performance of WPCs.

Modified rule of mixture and damage parameter. As Figure 2 shows, there was a significant decrease in the axial modulus of the cell wall for both wood species when we compared their properties before and after processing. There was a reduction in the modulus of about $40 \%$ and $70 \%$ for latewood and earlywood cells respectively. This significantly affects the damage parameter estimation (see Equation 4). Table 1 presents estimated averaged values for the damage parameter for wood species used in our experiments. It shows a generalized damage parameter related to extrusion-injection processes that can be used for further predictions using Equation 5 . Thus, $D=0.35$ may represent a good approximation in predicting the longitudinal modulus of composites made with identical processes.

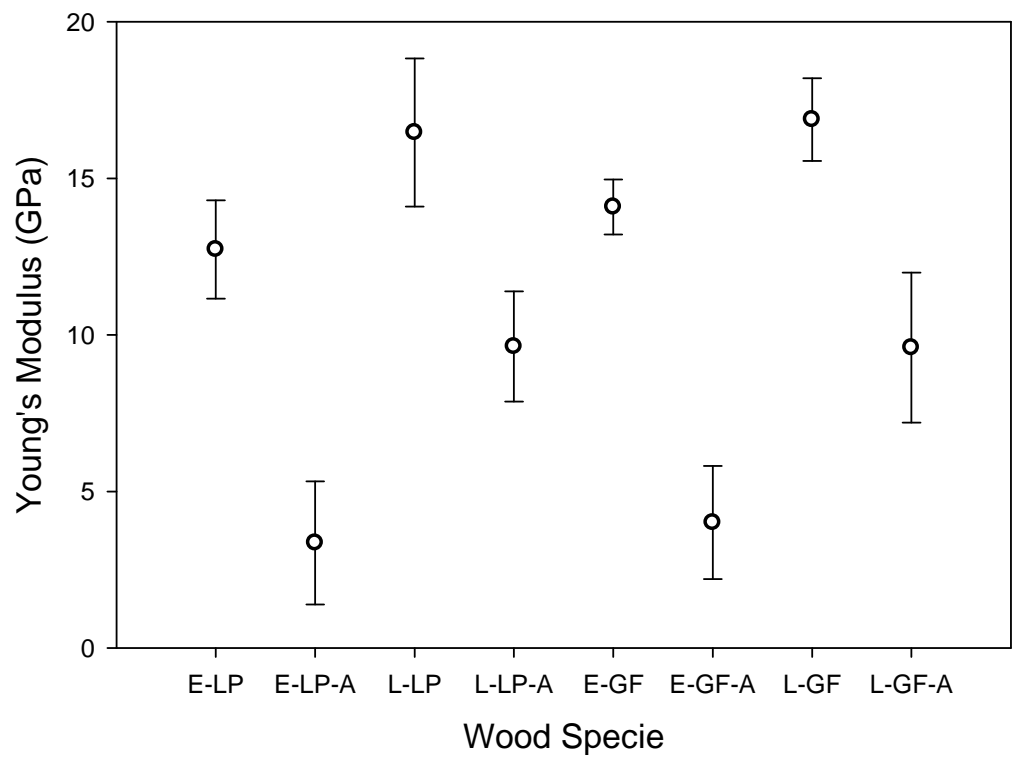

Figure 2: 95\% interval of confidence for reduction of the elastic modulus of wood flour particles after extrusion and injection molding. GF and LP are grand fir and lodgepole pine, respectively; $E$ is earlywood, $L$ is latewood, and A represents the modulus measurement after processing. 
Table 1: Average damage parameter for experimental natural filler (outerwood). Process: Extrusion-Injection.

\begin{tabular}{lcccc}
\hline Filler & $\begin{array}{c}E_{D E} \\
\text { Dimensionless }\end{array}$ & $\begin{array}{c}E_{D L} \\
\text { Dimensionless }\end{array}$ & $\begin{array}{c}D_{E} \text { or } D_{L} \\
\text { Dimensionless }\end{array}$ & $\begin{array}{c}D \\
\text { Dimensionless }\end{array}$ \\
\hline $\begin{array}{l}\text { Grand fir, } \\
\text { earlywood }\end{array}$ & 0.72 & --- & 0.218 & 0.350 \\
$\begin{array}{l}\text { Grand fir, } \\
\text { latewood }\end{array}$ & --- & 0.43 & 0.132 & 0.353 \\
\hline $\begin{array}{l}\text { Lodgepole pine, } \\
\text { earlywood }\end{array}$ & 0.73 & --- & 0.198 & \\
$\begin{array}{l}\text { Lodgepole pine, } \\
\text { latewood }\end{array}$ & --- & 0.42 & 0.155 & \\
\hline
\end{tabular}

Table 2: Comparison predicted-experimental values for composites made of $40 \%$ of wood flour (\% weight).

\begin{tabular}{lccc}
\hline Composite & $\begin{array}{c}E_{1}(\mathrm{GPa}) \\
\text { Experimental }\end{array}$ & $\begin{array}{c}E_{1}(\mathrm{GPa}) \\
\text { Predicted }\end{array}$ & Error $(\%)$ \\
\hline HDPE-LP & 2.50 & 3.75 & 50 \\
HDPE-GF & 3.41 & 4.60 & 35 \\
PP-pond. pine & 3.69 & 3.88 & 5 \\
\hline
\end{tabular}

MROM, validation. Figure 3 shows predictions of the longitudinal modulus for WPCs made of PP and Ponderosa pine using different weight fractions of the natural filler. The new materials used to validate the proposed model, based on the damage of the cell wall in processing, were subjected to identical extrusion and injection molding as before. The proposed MROM predicts very precisely the tensile modulus of the PP-Ponderosa pine composites (figure 3). A damage parameter, $D=0.35$ represents the impact of the particular manufacturing process used here for decreasing the properties of wood flour particles. As wood content increases, the estimation error also increases in predictions using MROM. For composites made of $40 \%$ of wood flour (\% weight), the prediction error was $50 \%$ and $35 \%$ for HDPE-LP and HDPE-GF wood composites respectively. Under similar conditions, the predicted error for PP-ponderosa pine composites was 5\%, which represents a very good estimation of the tensile modulus in the 1-Direction (Table 2). 


\section{Proceedings of the 51st International Convention of Society of Wood Science and Technology November 10-12, 2008 Concepción, CHILE}

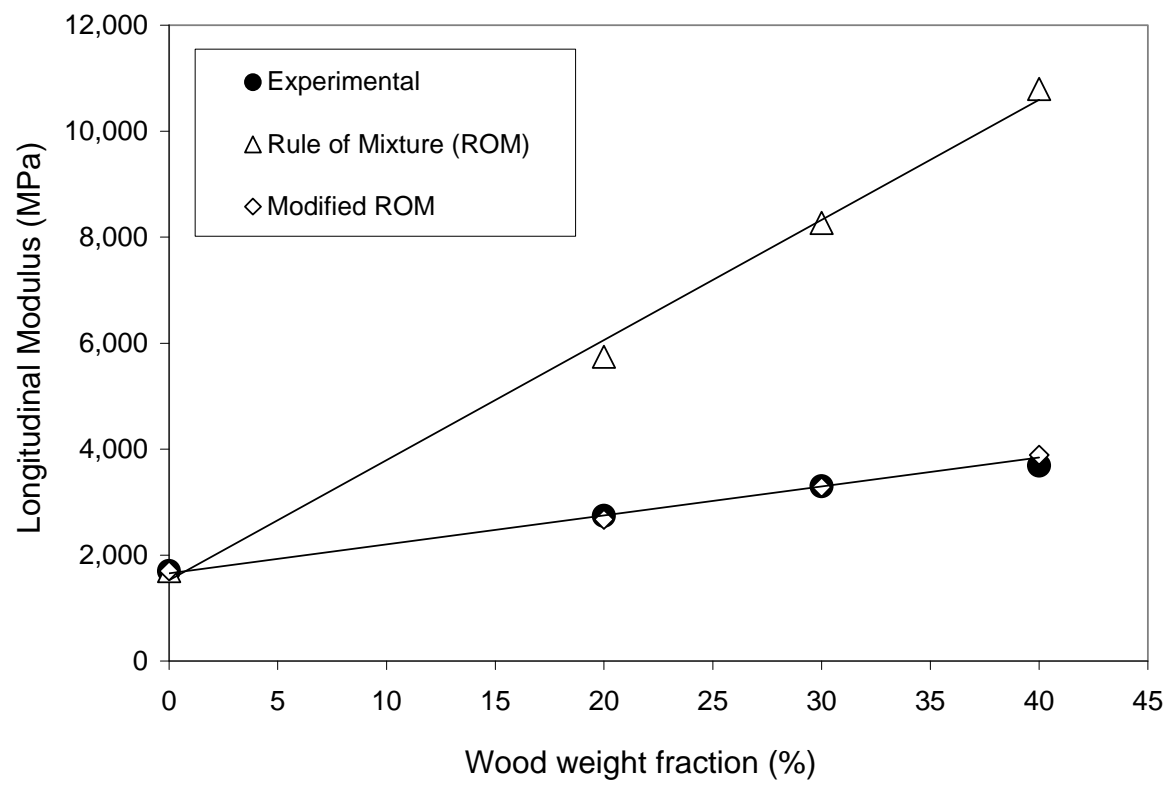

Figure 3: Comparison of experimental and predicted tensile modulus based on rule of mixture and the modified rule of mixture. PP-ponderosa pine composites.

\section{Conclusions}

There was a reduction in Young's modulus of the cell wall due to processing from $40 \%$ to $70 \%$. In general, the elastic modulus of the S2 layer was higher in latewood cells. These cells experienced lower collapse and damage than earlywood cells. The proposed new model introduced a modification or damage factor affecting the filler properties. The damage factor, which is a material parameter, was determined experimentally using nanoindentations. This factor represents the cumulative damage in wood cells due to processing, and is expressed as a reduction in modulus in the 1-Direction. This proposed model was very precise in predictions of the longitudinal modulus of WPCs.

\section{References}

Agarwal B.D., Broutman L.J. Analysis and performance of fiber composites. John Wiley \& Sons, Inc. 1990, p 59.

Geimer R., Mahoney R., Loehnertz S., Meyer R. Influences of processing-induced damage on strength of flakes and flakeboards. United states Department of agriculture, Forest Service, Forest Products Laboratory. Research paper FPL 463, 1985.

Gindl W., Gupta H.S. Cell-wall hardness and Young's modulus of melamine-modified spruce wood by nanoindentation. Composite part A. 2002; 33: 1141-1145.

Gindl W., Gupta H., Schoberl T., Lichtenegger H. Fratzl P. Mechanical properties of spruce wood cell walls by nanoindentation. Appl. Phys. A 2004; 79: 2069-2073.

Mark R.E. Cell wall mechanics of tracheids. Yale University, The McKay Press, Inc., Midland, Michigan. 1967. 


\section{Proceedings of the 51st International Convention of Society of Wood Science and Technology November 10-12, 2008 Concepción, CHILE}

Reiterert A., Lichtenegger H., Tscheggt S., Fratzl P. Experimental evidence for a mechanical function of the cellulose microfibril angle in wood cell walls. Philosophical magazine A 1999; 79(9): 2173-2184.

Salmen L. Micromechanical understanding of the cell-wall structure. C. R. Biologies 2004; 327: 873-880.

Snnedon I.N. Fourier Transforms, McGraw-Hill, New York 1951.

Snnedon I.N. Proc. Cambridge Philos. Soc. 44 (1948) 492.

Tucker C., Erwin L. Stiffness predictions for unidirectional short-fiber composites: Review and evaluation. Composites Science and Technology 1999; 59: 655-671

Wimmer R., Lucas B.N., Tsui T.Y., Oliver W.C. WC. Longitudinal hardness and Young's modulus of spruce tracheid secondary walls using nanoindentation technique. Wood Sci. Technol. 1997; 31: 131.

Wood handbook. Wood as an engineering material. General technical report FPL-GTR 113. Forest product laboratory, 1999. 